\title{
RPS2 wt Allele
}

National Cancer Institute

\section{Source}

National Cancer Institute. RPS2 wt Allele. NCI Thesaurus. Code C129267.

Human RPS2 wild-type allele is located in the vicinity of $16 \mathrm{p} 13.3$ and is approximately $3 \mathrm{~kb}$ in length. This allele, which encodes 40 S ribosomal protein S2, plays a role in ribosome assembly. 